ISSN: 2224-0616

Int. J. Agril. Res. Innov. Tech. 11(1): 10-16, June 2021

DOI: https://doi.org/10.3329/ijarit.v11i1.54461
OPEN 2 ACCESS

Available online at https://ijarit.webs.com https://www.banglajol.info/index.php/IJARIT

\title{
Determining an effective and economic fungicide spray schedule for reducing blast of wheat
}

\author{
M.H. Kabir ${ }^{1}$, F.S. Tisha ${ }^{2}$, H.R. Nayan ${ }^{2}$, M.A. Islam ${ }^{1}$, M.A. Kashem³ ${ }^{3}$ M.I. Uddin ${ }^{3}$, M.R. Islam ${ }^{4}$ and M.B. Meah4 $^{*}$
}

Received 7 February 2021, Revised 3 May 2021, Accepted 23 June 2021, Published online 30 June 2021

\begin{abstract}
A B S T R A C T
Wheat blast, caused by the fungus Magnaporthe oryzae pathotype Triticum (MoT), constitutes one of the major obstacles to the expansion of wheat production in Bangladesh. In the absence of resistant variety, fungicide control is the first-hand effort. Determining an effective and economic fungicide spray schedule in controlling blast disease of wheat was aimed. Ten fungicides were tested during two consecutive cropping seasons of 2018-2019 to 2019-2020. The wheat plants of blast susceptible cultivar BARI Gom 26 were inoculated with spores (107 spores $\left.\mathrm{ml}^{-1}\right)$ of MoT at pre-heading stage of wheat (52 days age). Fungicides were applied both before inoculation and after the appearance of blast symptoms in cocktail for three times starting from booting of wheat at 7 days interval. Plants received the combination of Filia (Tricyclazole 40\% + Propiconazole 12.5\%) and Seltima (Pyraclostrobin $10 \%)$ had significantly lower blast incidence and severity (1.23\% and $3.33 \%)$ against untreated plants. Cocktail of Nativo and Trooper (Tricyclazole $75 \mathrm{wp}$ ) proved $2^{\text {nd }}$ best curative measure. Application of Nativo (Tebuconazole 50\% + Trifloxystrobin 25\%) alone ranked third in its efficacy. The fungicide spray schedule covered booting, pre-heading and heading stages of wheat. The results indicate a mixture of Tebuconazole + Tricyclazole + Pyraclostrobin is more effective (97\% blast reduction) and economic (BCR 1.45) than a single compound application in reducing incidence and severity of wheat blast.
\end{abstract}

Keywords: Wheat blast, Fungicide spray schedule.

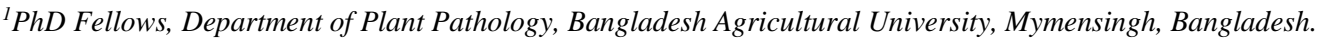

${ }^{2}$ MS Fellows, Department of Plant Pathology, Bangladesh Agricultural University, Mymensingh, Bangladesh.

${ }^{3}$ Research Scientist, Plant Pathology and Biotechnology, Bangladesh Institute of Nuclear Agriculture, Mymensingh, Bangladesh.

${ }^{4}$ Professor, Department of Plant Pathology, Bangladesh Agricultural University, Mymensingh, Bangladesh.

*Corresponding author’s email: bmeah@yahoo.com (M.B. Meah)

Cite this article as: Kabir, M.H., Tisha, F.S., Nayan, H.R., Islam, M.A., Kashem, M.A., Uddin, M.I., Islam, M.R. and Meah, M.B. 2021. Determining an effective and economic fungicide spray schedule for reducing blast of wheat. Int. J. Agril. Res. Innov. Tech. 11(1): 10-16. https://doi.org/10.3329/ijarit.v11i1.54461

\section{Introduction}

Wheat is the second most important staple food crop in Bangladesh after rice (Karim et al., 2010). Within a period of 30 years of time, it has been firmly established as a secure crop in Bangladesh, mainly due to stable market price and involvement of huge farmers. With the emergence of new biotic cause, an added stress to climate change and the rapidly declining per capita arable land, meeting the demand to supply of wheat is increasingly challenging and threatening to food production and food security in developing country like Bangladesh (World Bank, 2016). In 2016, the devastating wheat-blast disease caused by the fungus Magnaporthe oryzae pathotype Triticum (MoT) was reported in Bangladesh (Callaway, 2016).
Blast attacks the rachis, leading to bleached spikelets above the point of infection and bright black spots on the rachis (Duveiller et al., 2016). Grains from blast-infected heads are usually small, shriveled and deformed. The highest yield losses happen when head infections start during anthesis or early grain development stages. At present, most of the commercially grown wheat cultivars in South Asia are susceptible to wheat blast, BARI Gom 33 released as blast resistant variety is in farmer's field (Hossain et al, 2019). The level of yield losses and speed of epidemics caused by MoT along with the lack of resistance may require innovative approaches to manage this disease. Chemical fungicides spray remains the main approach for controlling wheat blast until a dependable resistant cultivar is developed. 
Application of single chemical compound such as tebuconazole or tricyclazole or trifloxystrobin proved not effective in reducing blast disease severity (Urashima et al., 2009). Mixture of two of these compounds when applied produced better results (Valent et al., 2016; Rios et al., 2016), may be combination of all the three compatible compounds might yield significantly better results. Other important side is that these fungicides acted well when applied before the appearance of blast disease as preventive measure, not providing curative action once the spike started bleaching. Therefore, the present study was designed for finding out fungicide(s) and an effective spray schedule as both preventive and curative measures against incidence and severity of wheat blast.

\section{Materials and Methods}

\section{Experimental site}

The experiments were conducted during the cropping seasons of 2018-19 and 2019-20 in the laboratory and net house of Plant Pathology Department, Bangladesh Agricultural University, and Plant Pathology Division, Bangladesh Institute of Nuclear Agriculture. Blast susceptible wheat variety BARI Gom 26 was used in the research work.

\section{Fungicides used in the experiment}

Ten fungicides collected from local market and marketing industries were used (Table 1) in the experiment.

Table 1. Fungicides used in the experiments.

\begin{tabular}{|c|c|c|c|c|}
\hline Treatments & $\begin{array}{c}\text { Name of } \\
\text { Fungicides }\end{array}$ & Groups & $\begin{array}{l}\text { Concentration } \\
\text { used in bioassay } \\
(\mathrm{ppm})\end{array}$ & $\begin{array}{c}\text { Doses applied* } \\
\text { in the net } \\
\text { house }\end{array}$ \\
\hline $\mathrm{F}_{\mathrm{o}}$ & Control & - & 00.00 & 00.00 \\
\hline $\mathrm{F}_{1}$ & Nativo & $\begin{array}{l}\text { Tebuconazole } 50 \% \\
+ \text { Trifloxystrobin } 25 \% \\
\text { w/w WG }\end{array}$ & 600 & $6{\mathrm{~g} 10 \mathrm{~L}^{-1}}$ \\
\hline $\mathrm{F}_{2}$ & Filia & $\begin{array}{c}\text { Tricyclazole } 40 \%+ \\
\text { Propiconazole } 12.5 \%\end{array}$ & 2000 & 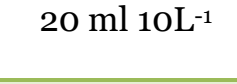 \\
\hline $\mathrm{F}_{3}$ & Seltima & Pyraclostrobin $10 \%$ & 2000 & $20{\mathrm{ml} 10 \mathrm{~L}^{-1}}^{-1}$ \\
\hline $\mathrm{F}_{4}$ & Kaicin & $\begin{array}{c}\text { Kasugamycin } 3 \%+ \\
\text { Tricyclazole } 77 \%\end{array}$ & 500 & $5{\mathrm{~g} 10 \mathrm{~L}^{-1}}^{-1}$ \\
\hline $\mathrm{F}_{5}$ & Edifen & Edifenphos 50\% & 1700 & $17{\mathrm{ml} 10 \mathrm{~L}^{-1}}^{-1}$ \\
\hline $\mathrm{F}_{6}$ & $\begin{array}{c}\text { Diaben } \\
\text { (Amistar Top) }\end{array}$ & $\begin{array}{c}\text { Azoxystrobin } 20 \% \\
\text { + Difenoconazole } \\
12.5 \%\end{array}$ & 1000 & $10{\mathrm{ml} 10 \mathrm{~L}^{-1}}^{-1}$ \\
\hline $\mathrm{F}_{7}$ & Trooper & Tricyclazole 75 WP & 800 & $8{\mathrm{~g} 10 \mathrm{~L}^{-1}}^{-1}$ \\
\hline $\mathrm{F}_{8}$ & SunFighter & $\begin{array}{c}\text { Hexaconazole } 3 \%+ \\
\text { Tricyclazole } 22 \%\end{array}$ & 2000 & $20{\mathrm{ml} 10 \mathrm{~L}^{-1}}^{-1}$ \\
\hline $\mathrm{F}_{9}$ & Score & Difenoconazole $25 \%$ & 2000 & 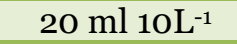 \\
\hline $\mathrm{F}_{10}$ & Provax $200 \mathrm{WP}$ & $\begin{array}{l}\text { Carboxin } 17.5 \% \\
+ \text { Thiram } 17.5 \%\end{array}$ & 0.03 & $3 \mathrm{~g} \mathrm{~kg}^{-1}$ seed \\
\hline
\end{tabular}

*Doses as recommended for commercial application.

\section{Bioassay offungicides}

The linear growth $(\mathrm{cm})$ and \% growth inhibition of mycelium of Magnaporthe oryzae Triticum (MoT) were observed in vitro by poisoned food technique (Nene and Thapliyal, 1979) (Table 2).

In this Technique, fungicide solution was prepared by dissolving requisite quantity of chemical in sterilized water. From PDA plate, three $5.0 \mathrm{~mm}$ discs of the medium was scooped off three places maintaining an equal distance from the centre by a sterilized disc cutter. One milliliter of fungicides solution was put into each hole and the plates were stored overnight in refrigerator for diffusion of the input in the medium around the hole. The next day, one 5 $\mathrm{mm}$ culture block of MoT (20 days old) was cut and placed at the centre of the treated PDA plate. For control treatment, only sterile water was used instead of fungicides. The plates were then placed at $30 \pm 1^{\circ} \mathrm{C}$ for 20 days.

\section{Measurement of growth of MoT and \% growth inhibition}

The linear growth $(\mathrm{cm})$ of mycelium of MoT was recorded at 2 days interval until the control plates were filled in. Efficacy of the treatments in inhibiting radial mycelial growth of MoT in vitro was determined by the following formula:

$$
\begin{aligned}
& \text { Mycelia growth inhibition }(\%)= \\
& \frac{\text { Mycelia growth }(\text { dia }) \text { in the treated plate }(\mathrm{mm})}{\text { Mycelia growth in the control plate }(\mathrm{mm})} \times 100
\end{aligned}
$$




\section{Preparation of experimental pot and sowing of seed}

Each of the plastic pots were filled up with $16 \mathrm{~kg}$ silt-loamy soil. Thirty (30) seeds were sown on 30 November 2018 and 2019 in each of the prepared pots. Thinning was done at 20 days after sowing (DAS) to maintain 15 plants per pot. The fertilizers were applied in each pot as per the Fertilizer Recommendation Guide (BARC, 2018). Weeding and watering was uniformly done when required.

\section{Culture of M. oryzae Pathotype Triticum}

Pure culture of MoT was collected from IPM Lab, Bangladesh Agricultural University. The culture was multiplied in Oatmeal agar media. The plates were incubated at $30 \pm 1^{\circ} \mathrm{C}$ with continuous NUV light (650 lux) for 15-20 days for sporulation (Fig. 1). Density of the spores was calculated by harvesting the conidia/mycelia by flooding the Petri dish with $5 \mathrm{ml}$ of sterile distilled water and dislodging the conidia with a bent glass rod. Spore density was $1 \times 10^{7}$ per $\mathrm{ml}$ as it was calculated in Hemocytometer count. The germination ability of the spores was checked through continued microscopic observation of the slide prepared out of spore suspension.

\section{Inoculation of the test pathogen (MoT)}

Wheat plants of blast susceptible variety BARI Gom 26 grown in pot soil were inoculated with Magnaporthe oryzae Triticum spores @ 10 7 CFU. Wheat plants at the age of 52 days i.e. preheading stage were inoculated. After inoculation, the plants were kept covered under polythene shed for $48 \mathrm{~h}$ to maintain high humidity ( $>80 \%$ $\mathrm{RH}$ ) and temperature $30 \pm 1^{\circ} \mathrm{C}$. Observations were made for the expression of blast disease symptoms. Isolation of the causal organism was made from infection court for the confirmation of successful infection by Magnaporthe oryzae Triticum (Fig. 1).
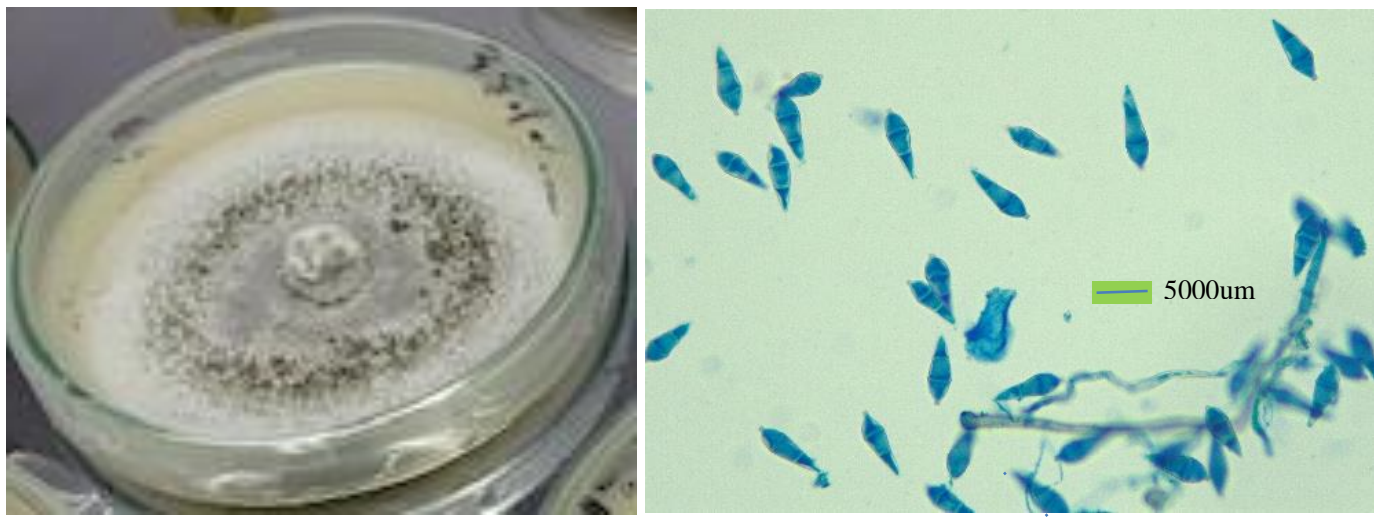

Fig. 1. Culture (20 days old) and typical 2-septate 3-celled pyriform spores of Magnaporthe oryzae Triticum (Microscopic view 40x).

\section{Spraying fungicide-suspension}

As preventive measure, first spray of fungicides was given at booting stage (47 days age) of wheat plants i.e. before the appearance of any blast symptoms. Two sprays during 2018-19 and three sprays during 2019-20 cropping seasons were applied at 10 days interval. The third spray during 2019-20 served as curative measure as was given on-sight blast symptoms i.e. 14 days after inoculation with MoT, at 66 days age of the wheat plant.

\section{Treatments and design of experiment}

In the cropping season of 2018-19, eight fungicides each at single doses were used. There were nine treatments including control. During the cropping season of 2019-20, seven fungicides selected out of previous year's trial including two new were applied either single or mixture of two at single doses of each. There were eight treatments including control. The treatments were set following completely randomized design (CRD) with three replications.

\section{Data collection}

The incidence of wheat blast and its severity were scored for four times during 2018-19 and five times during 2019-20 experiments at two days interval starting at 68 days age of the plants i.e. 2 days after symptoms expression.

Disease Incidence: Number of spikes infected per replication expressed in percentage (Rajput and Bartaria, 1995). \% blast incidence $=\mathrm{Pi} / \mathrm{Pt} \mathrm{x}$ 100 where, $\mathrm{Pi}=$ Number of spikes infected, and $\mathrm{Pt}=$ Total number of spikes counted.

Disease Severity: Percent area of spike infected/bleached was estimated. Spikes per pot were counted and arithmetic means for single plants were calculated. Disease severity was scored following the figures shown below given by Maciel et al. (2013): $0=$ No lesion, $1=25 \%$ or less, $2=26-50 \%, 3=51-75 \%$ and $4=76-100 \%$. 


\section{Statistical analysis of data}

The data were statistically analyzed using Minitab 18 computer package program and means were compared by DMRT (Duncan's Multiple Range Test).

\section{Results and Discussion}

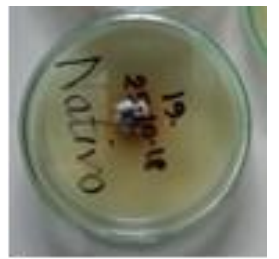

Nativo

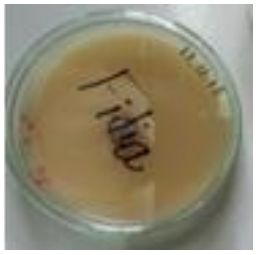

Filia

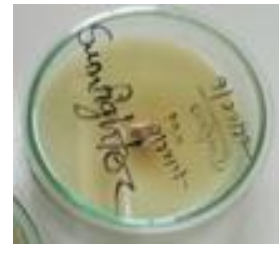

SunFighter

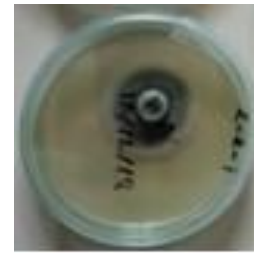

Trooper

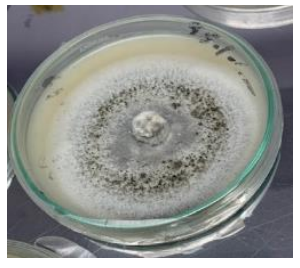

Control

Fig. 2. Growth of Magnaporthe oryzae Triticum on PDA poisoned with fungicides at 20 days after inoculation.

\section{Spraying fungicides at booting stage of wheat}

Symptoms appeared approximately 14 days after inoculation in untreated (control) plants. The treated plants also showed blast infection almost at the same time. Typical blast symptoms of spike bleaching advancing from top to downward were observed (Fig. 3).

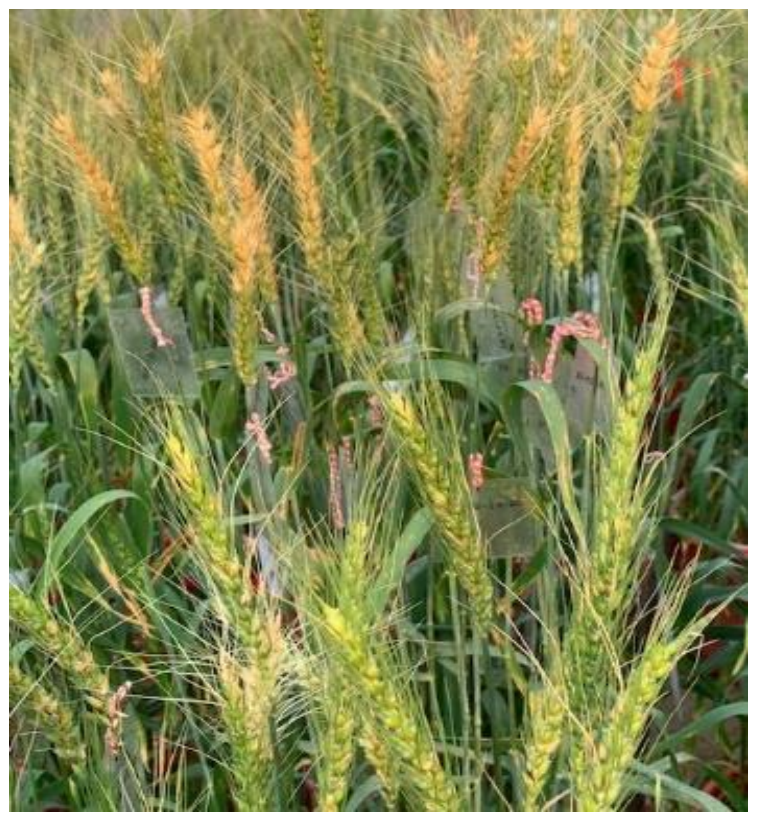

Fig. 3. Typical spike bleaching of wheat plants of variety BARI Gom26 inoculated with Magnaporthe oryzae Triticum in the BINA net house.
Both blast incidence and severity were monitored for 12 days from the 2nd day of the on sight of the blast disease. In the cropping season 2018-19, none of the fungicides displayed any good results. Nativo, Sun Fighter and Filia treated plants had 33,30 and $27 \%$ less incidence of blast, respectively. During 2019-2020, wheat plants receiving no fungicide sprays had a continued increase in spike bleaching showing $100 \%$ blast incidence on the 80 days age. Blast incidence either remained static or increased slowly on the wheat plants sprayed with fungicides. Seed treatment did not have any effect on the incidence of wheat blast (Table 2).

Wheat plants treated with single, or mixture of fungicides had significantly different levels of blast incidence. F5 (Filia@2.0 ml L-1 + Seltima @ 2.0 $\mathrm{ml} \mathrm{L}^{-1}$ ) treated plants didn't show blast symptoms up to 70 days age, only $1.23 \%$ plants had bleached spike finally. Wheat plants treated with other six fungicides showed blast symptoms from 68 days age. F4 and F1 treated plants had significantly lower blast incidence of 6.71 and $8.12 \%$, respectively. As per the performance of disease incidence, spraying cocktail of F5 (Filia @ 2.0 $\mathrm{ml} \mathrm{L}^{-1}+$ Seltima @ 2.0 $\mathrm{ml} \mathrm{L}^{-1}$ ) was found the best where $98.77 \%$ reduction of disease was observed over control at 80 DAS. The blast incidence recorded for the spraying of $\mathrm{F}_{4}$ (Nativo + Trooper) and F1 (Nativo) were statistically similar to that of $\mathrm{F}_{5}$. So, F4 treatment i.e., mixture of Nativo and Trooper proved as the second-best treatment (Table 2). 
Table 2. Effect of three sprays of fungicide as preventive measure starting from booting stage in reducing incidence of wheat blast in the net house of BINA during 2019-2020 cropping season.

\begin{tabular}{|l|c|c|c|c|c|}
\hline \multicolumn{1}{|c|}{ Treatments } & \multicolumn{5}{c|}{ Disease Incidence (\%) } \\
\hline $\mathrm{F}_{\mathrm{O}}$ & $68 \mathrm{DAS}$ & $71 \mathrm{DAS}$ & $74 \mathrm{DAS}$ & $77 \mathrm{DAS}$ & $80 \mathrm{DAS}$ \\
\hline $\mathrm{F}_{1}$ & $30.00 \mathrm{a}$ & $38.30 \mathrm{a}$ & $54.03 \mathrm{a}$ & $78.89 \mathrm{a}$ & $100.00 \mathrm{a}$ \\
\hline $\mathrm{F}_{2}$ & $3.36 \mathrm{~b}$ & $4.75 \mathrm{~b}$ & $4.75 \mathrm{~b}$ & $4.75 \mathrm{c}$ & $8.12 \mathrm{~cd}$ \\
\hline $\mathrm{F}_{3}$ & $4.303 \mathrm{~b}$ & $5.493 \mathrm{~b}$ & $5.510 \mathrm{~b}$ & $6.793 \mathrm{c}$ & $9.930 \mathrm{~cd}$ \\
\hline $\mathrm{F}_{4}$ & $4.517 \mathrm{~b}$ & $5.800 \mathrm{~b}$ & $7.650 \mathrm{~b}$ & $9.500 \mathrm{c}$ & $12.750 \mathrm{c}$ \\
\hline $\mathrm{F}_{5}$ & $3.00 \mathrm{~b}$ & $3.00 \mathrm{~b}$ & $4.33 \mathrm{~b}$ & $4.33 \mathrm{c}$ & $6.713 \mathrm{~cd}$ \\
\hline $\mathrm{F}_{6}$ & $0.00 \mathrm{~b}$ & $0.00 \mathrm{~b}$ & $1.23 \mathrm{~b}$ & $1.23 \mathrm{c}$ & $1.23 \mathrm{~d}$ \\
\hline $\mathrm{F}_{7}$ & $5.89 \mathrm{~b}$ & $5.89 \mathrm{~b}$ & $8.93 \mathrm{~b}$ & $8.93 \mathrm{c}$ & $11.96 . \mathrm{cd}$ \\
\hline $\mathrm{CV}(\%)$ & $26.41 \mathrm{a}$ & $33.01 \mathrm{a}$ & $46.22 \mathrm{a}$ & $60.67 \mathrm{~b}$ & $85.55 \mathrm{~b}$ \\
\hline $\mathrm{LSD}(0.05)$ & 33.91 & 43.46 & 33.06 & 17.92 & 10.21 \\
\hline
\end{tabular}

$F_{o}=0 . o$ (Tape water), $F_{1}=$ Nativo @ o.6 $\mathrm{g} \mathrm{L}^{-1}, F_{2}=$ Filia @ $2.0 \mathrm{ml} \mathrm{L} \mathrm{L}^{-1}, F_{3}=$ SunFighter @ $2.0 \mathrm{ml} \mathrm{L}^{-1}$

$F_{4}=$ Nativo @o.6 g L $L^{-1}+$ Trooper @o.8 $\mathrm{gL}^{-1}, F_{5}=$ Filia @ 2.o ml L-1 + Seltima @ $2.0 \mathrm{ml} \mathrm{L}^{-1}$

$F_{6}=$ SunFighter @ 2.o ml L ${ }^{-1}+$ Score 25oEC @ $1.0 \mathrm{ml} \mathrm{L} \mathrm{L}^{-1}, F_{7}=$ Provax @ $3 \mathrm{~g} \mathrm{~kg}^{-1}$ seed.

Figures in a column with different letters are significantly different. DAS: Days After Sowing.

Severity of blast disease was significantly reduced for fungicide sprays. F5 treatment i.e., cocktail of Filia and Seltima spray reduced blast severity by 97\% over untreated. Treatments F4 and F1 displayed statistically similar effect, reduced blast severity by 87 and $82 \%$, respectively (Table 3 ). Seed treatment did not have any effect on spike bleaching of wheat.

\section{Yield and $B C R$}

Table 3. Effect of three sprays of fungicide as preventive measure starting from booting stage in reducing severity of wheat blast in the net house of BINA during 2019-2020 cropping season.

\begin{tabular}{|c|c|c|c|c|c|c|c|}
\hline \multirow[t]{2}{*}{ Treatments } & \multicolumn{5}{|c|}{ Disease Severity (\%) } & \multirow{2}{*}{$\begin{array}{c}\text { Yield } \\
(\text { ton ha-1) }\end{array}$} & \multirow{2}{*}{$\begin{array}{l}\text { Benefit Cost } \\
\text { Ratio(BCR) }\end{array}$} \\
\hline & 68 DAS & 71 DAS & 74 DAS & 77 DAS & 8o DAS & & \\
\hline $\mathrm{F}_{\mathrm{O}}$ & $44.67 \mathrm{a}$ & $58.33 \mathrm{a}$ & $71.67 \mathrm{a}$ & $79.33 \mathrm{a}$ & $98.00 \mathrm{a}$ & $0.2767 \mathrm{e}$ & 0.092 \\
\hline $\mathrm{F}_{1}$ & $10.67 \mathrm{~b}$ & $11.33 \mathrm{~b}$ & $12.00 \mathrm{~b}$ & $12.67 \mathrm{~b}$ & $17.33 \mathrm{~b}$ & $3.6000 \mathrm{~b}$ & 1.160 \\
\hline $\mathrm{F}_{2}$ & $8.33 \mathrm{~b}$ & $10.00 \mathrm{~b}$ & $15.00 \mathrm{~b}$ & $18.67 \mathrm{~b}$ & $27.67 \mathrm{~b}$ & $3.1340 \mathrm{bc}$ & 1.009 \\
\hline $\mathrm{F}_{3}$ & $6.00 \mathrm{~b}$ & $8.00 \mathrm{~b}$ & $16.67 \mathrm{~b}$ & $23.00 \mathrm{~b}$ & $32.70 \mathrm{~b}$ & $2.9670 \mathrm{c}$ & 0.950 \\
\hline $\mathrm{F}_{4}$ & $6.00 \mathrm{~b}$ & $7.33 \mathrm{~b}$ & $7.33 \mathrm{~b}$ & $7.33 \mathrm{~b}$ & $13.00 \mathrm{~b}$ & $4.1930 \mathrm{a}$ & 1.350 \\
\hline $\mathrm{F}_{5}$ & $0.00 \mathrm{~b}$ & $0.00 \mathrm{~b}$ & $1.67 \mathrm{~b}$ & $2.67 \mathrm{~b}$ & $3.33 \mathrm{~b}$ & $4.5210 \mathrm{a}$ & 1.450 \\
\hline $\mathrm{F}_{6}$ & $9.33 \mathrm{~b}$ & $12.33 \mathrm{~b}$ & $15 \cdot 33 \mathrm{~b}$ & $20.00 \mathrm{~b}$ & $29.33 \mathrm{~b}$ & $3.0670 \mathrm{bc}$ & 0.990 \\
\hline $\mathrm{F}_{7}$ & $42.00 \mathrm{a}$ & $55.67 \mathrm{a}$ & $60.33 a$ & $68.00 \mathrm{a}$ & $86.33 \mathrm{a}$ & $0.9660 \mathrm{~d}$ & 0.318 \\
\hline CV (\%) & 48.73 & 31.64 & 34.93 & 27.96 & 23.40 & 9.63 & - \\
\hline LSD(0.05) & 16.87 & 13.51 & 16.53 & 16.29 & 19.25 & 0.547 & - \\
\hline
\end{tabular}

$F_{o}=0 . o$ (Tape water), $F_{1}=$ Nativo @ o.6 $g L^{-1}, F_{2}=$ Filia @ $2.0 \mathrm{ml} \mathrm{L}^{-1}, F_{3}=$ SunFighter @ $2.0 \mathrm{ml} \mathrm{L}^{-1}$

$F_{4}=$ Nativo@o.6g L $L^{-1}+$ Trooper @o.8 $\mathrm{gL}^{-1}, F_{5}=$ Filia @ $2.0 \mathrm{ml} \mathrm{L}^{-1}+$ Seltima @ $2.0 \mathrm{ml} \mathrm{L}^{-1}$

$F_{6}=$ SunFighter@2.o ml L-1 + Score 25oEC @1.0 ml L-1, $F_{7}=$ Provax @ $3 g \mathrm{~kg}^{-1}$ seed.

Figures in a column with different letters are significantly different, DAS: Days After Sowing.

Both the blast incidence and severity increased with time in both the untreated plants $\left(\mathrm{F}_{0}\right)$ and plants sprayed with fungicides. Similar trend was observed in plants raised from Provax treated seeds $\left(\mathrm{F}_{7}\right)$. In case of plants sprayed with cocktail of Filia and Seltima $\left(\mathrm{F}_{5}\right)$, Nativo and Trooper $\left(\mathrm{F}_{4}\right)$ and Nativo alone $\left(\mathrm{F}_{1}\right)$, incidence and severity of spike blast had a reduced rate of increase (Figure 4). On the other hand, seed treatment with fungicide could not prevent blast infection or stop its motion. At 80 days of the crop, blast incidence and severity reached nearly to $100 \%$ in the untreated plants while at this time, the plants sprayed with the cocktail of Filia and Seltima had blast incidence and severity of 1.23 and $3.33 \%$, respectively (Fig. 4). F5 treated plants did not show blast infection up to 71 days age of the crop. 


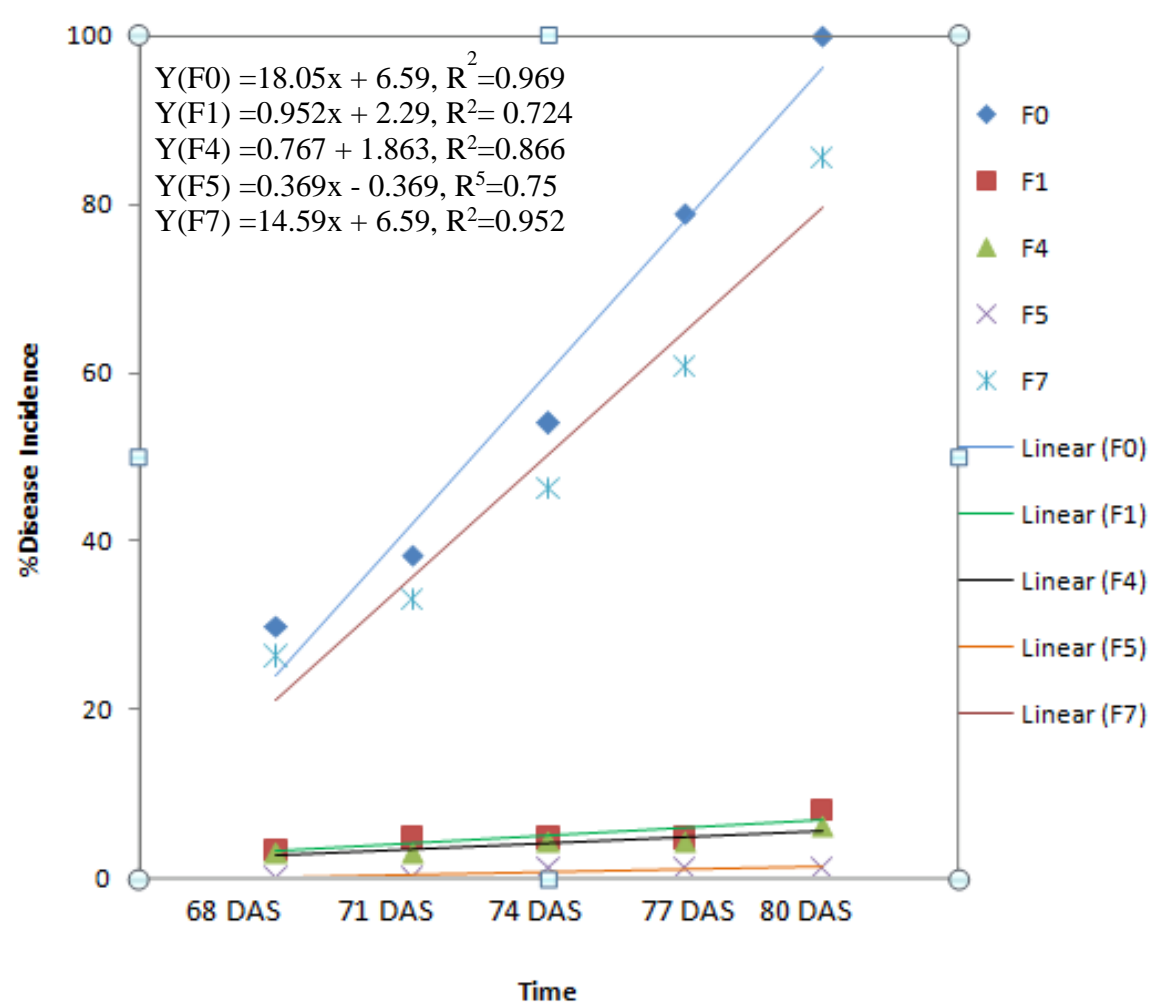

Fig. 4. Reduction of incidence of wheat blast as intervened by spray of cocktail of fungicides. DAS: Days After Sowing, $\mathrm{F}_{0}$ : untreated, $\mathrm{F}_{1}$ : Nativo, $\mathrm{F}_{4}$ : Nativo + Trooper, $\mathrm{F}_{5}$ : Filia + Seltima, $\mathrm{F}_{7}$ : Seed treatment with Provax $3 \mathrm{~g} \mathrm{~kg}^{-1}$ of seed.

Wheat blast appeared with fears in Bangladesh in 2016, had been fearsome to Brazil and Bolivia since 1985 . The production loss is $100 \%$ if spikes were infected at heading stage (Hossain et al., 2019). Management of wheat blast is, therefore, a must. Because wheat shares a vital role in attaining food security of Bangladesh and countries like Brazil, Bolivia, Nepal, Pakistan and India (Duveiller et al., 2016). In the absence of durable blast resistant variety, other means of management practices such as fungicides, nutrient supplementation are in the front to adopt. Blast pathogen has also evolved to acquire resistance to fungicides extensively used to manage the disease (Oliveira et al., 2015). However, present findings concede the opinion of Bockus et al. (2014) that effective fungicides spray can reduce MoT sporulation by 52.2 to $100 \%$.

In the present investigation, perfect control of wheat blast could not be achieved. It might be because of the insufficient protection given by only one spray of the fungicides at heading stage. This finding partially agrees with Valent et al. (2016) who found combined application of triazoles effective in controlling wheat blast in heading stage in moderately resistant variety. Continued spray could bring better result, but it would cause increase in production cost.

Solo spray of Trooper, Filia, Seltima, Nativo and SunFighter could not stop blast infection motion. However, combined use of Filia and Seltima, and Nativo and Trooper brought the blast incidence and severity to a satisfactory level yielding a good return of wheat yield. The results indicated the combined spray of Tricyclazole, propiconazole and pyraclostrobin was the best curative measure. The results are supported by Rocha et al. (2014) who reported considerable reduction of wheat blast infection through use of pyraclostrobin and trifloxystrobin.

Three sprays of combined application of Filia and Seltima covered the three blast vulnerable growth stages of booting, pre-heading and heading served as both preventive and curative measures. Spore inoculation was done at pre-heading stage, those spores failed to germinate and penetrate into host tissues in the presence of the fungicide. Second spray at pre-heading stage might have killed spores from any external source. Third spray at heading stage kept the emerging spikes free of blast infection. This approach reduced blast infection by $97 \%$ and gave a very good yield, $>4.5$ ton ha $^{-1}$ which is higher than national average of 3.6 ton $\mathrm{ha}^{-1}$ in Bangladesh (BBS, 2019).

Our research indicates both Filia + Seltima mixture and Nativo + Trooper mixture are equally effective in wheat blast disease control. The third choice is solo application of Nativo. These results will help farmers to alternatively using any one of the three groups of fungicides just avoiding repetition, a right step to combat the mutation effect of Magnaporthe oryzae Triticum if any (Castroagudin et al., 2015; Oliveira et al., 2015). 


\section{Conclusion}

Three sprays of cocktail of (Tebuconazole + Propiconazole + Pyraclostobin) beginning from booting of wheat reduced blast severity by $97 \%$ on susceptible wheat variety and produced $>4.5$ ton ha-1 yield with BCR 1.45 .

\section{Acknowledgement}

Krishi Gobeshona Foundation (KGF) (CN/FRPP: $\mathrm{CF}-5 \mathrm{O}-\mathrm{C} / 17$ ) is gratefully acknowledged for financing the research work.

\section{References}

BARC. 2018. Fertilizer recommendation guide. Bangladesh Agricultural Research Council, Farmgate, Dhaka. 233 p.

BBS. 2019. Estimates of Wheat, 2017-18. Agric. Wing, Bangladesh Bur. Stat. Gov. Bangladesh.

http://bbs.portal.gov.bd/sites/default/files/files/ bbs.portal.gov.bd/page/16d38ef2_2163_4252_a 28b_e65f6odab8a9/wheat2018.pdf.

Bockus, W., Cruz, C.C., Stack, J.P. and Valent, B. 2014. Effect of seed-treatment fungicides on sporulation of Magnaporthe oryzae from wheat seed, PDMR. Report No. 9: ST 004. APS/Kansas State University.

Callaway, E. 2016. Devastating wheat fungus appears in Asia for the first time. Nature. 532(7600): 421-422. https://doi.org/10.1038/532421a

Castroagudin, V.L., Ceresini, P.C., de Oliveira, S.C., Juliana, T.A., Reges, J.T.A., Maciel, J.L.N., Bonato, A.L.V., Dorigan, A.F. and McDonald, B.A. 2015. Resistance to Qol fungicides is widespread in Brazilian populations of the wheat blast pathogen Magnaporthe oryzae. Phytopath. 105: 284294.

https://doi.org/10.1094/PHYTO-06-14-0184-R

Duveiller, E., He, X. and Singh, P.K. 2016. Wheat Blast: An Emerging Disease in South America Potentially Threatening Wheat Production. A History of Wheat 3 11071122. In: Hemming, D, (ed) Plant Sciences Reviews CABI, UK. pp. 233-240.

Hossain, A., Mottaleb, K.A., Farhad, M. and Barma, N.C.D. 2019. Mitigating the twin problems of malnutrition and wheat blast by one wheat variety, 'BARI Gom 33', in Bangladesh. Acta Agrobot. 72(2): 1775. https://doi.org/10.5586/aa.1775

Karim, M.R., Awal, M.A. and Akter, M. 2010. Forecasting of wheat production in
Bangladesh. Bangladesh J. Agril. Res. 35(1): 17-28.

Maciel, J.L.N., Danelli, A.L.D., Boaretto, C. and Forcelini, C.A. 2013. Diagrammatic scale for the assessment of blast on wheat spikes. Summa Phytopath. 39: 162-166.

https://doi.org/10.1590/So100-54052013000300003

Nene, Y.L. and Thapliyal, P.N. 1979. Fungicides in plant disease control. Second Edition. Oxford and IBH Publication Co. New Delhi. $507 \mathrm{p}$.

Oliveira, S.C., Castroagudin, V.L., Maciel, J.L.N., Pereira, D.A., Dos, S. and Ceresini, P.C. 2015. Cross-resistance to Qol fungicides azoxystrobin and pyraclostrobin in the wheat blast pathogen Pyricularia oryzae in Brazil. Summa Phytopath. 41: 298-304. https://doi.org/10.1590/0100-5405/2072

Rajput, R.L. and Bartaria, A.M. 1995. Reaction of rice cultivars to brown spot. Agric. Sci. Dig. Karnal. 15: 205-206.

Rios, J.A., Rios, V.S., Paul, P.A., Souza, M.A., Araujo, L. and Rodrigues, F.A. 2016. Fungicide and cultivar effects on the development and temporal progress of wheat blast under field conditions. Crop Protec. 89: 152-160.

https://doi.org/10.1016/j.cropro.2016.07.020

Rocha, J.R.A.S.C., Pimentel, A.J.B., Ribeiro G. and Souza, M.A. 2014. Efficiency of fungicides in wheat blast control. Summa Phytopath. 40: 347-352.

https://doi.org/10.1590/0100-5405/1937

Urashima, A., Grosso, C., Stabili, A., Freitas, E.G., Silva, C.P., Netto, D.C.S., Franco, I. and Merola Bottan, J.H. 2009. Effect of Magnaporthe grisea on seed germination, yield and quality of wheat. In: Wang G, Valent B, eds. Advances in Genetic, Genomics and Control of Rice Blast Disease. New York, USA: Springer Science and Business Media. pp. 267-77.

https://doi.org/10.1007/978-1-4020-9500-9_27

Valent, B., Cruz, C.D., Farman, M., Peterson, G.L., Pedley, K., Bockus, W.W., NaviaUrrutiu, M., Oliveira-Garcia, E., Kiyunal, J.G., Trick, H.N., Nunes-Maciela Paul, P.A. and Stack, J. 2016. Strategies for managing blast disease of wheat. Abstracts. Achieving durable resistance to wheat diseases and pests. 2-3 November 2016, Minneapolis, USA. 5 p.

World Bank. 2016. Washington DC: World Bank; Available from URL:

http://data.worldbank.org/indicator/NY.GDP.PC AP.CD?view=chart 